\title{
RUI BARBOSA, CONSTITUIÇÃO E INTERVENCIONISMO ESTATAL NA PRIMEIRA REPÚBLICA BRASILEIRA
}

\author{
RUI BARBOSA, CONSTITUTION AND FEDERAL \\ INTERVENTIONISM IN THE BRAZILIAN FIRST REPUBLIC
}

\author{
Fernanda Cristina Covolan \\ Centro Universitário Adventista de São Paulo \\ Tayná da Silva Marques do Rio \\ Centro Universitário Adventista de São Paulo
}

SUMÁRIO: I. INTRODUÇÃO.- II. INTERVENÇÃO ECONÔMICA NA PRIMEIRA REPÚBLICA.- III. LEGISLAÇÃO E INTERVENÇÃO ECONÔMICA NA PRIMEIRA REPÚBLICA.- IV. REVISÃO CONSTITUCIONAL E A FIGURA DE RUI BARBOSA.V. CONSIDERAÇÕES FINAIS

Resumo: Esta pesquisa desejou analisar as narrativas político-jurídicas da primeira Constituição brasileira, de 1891, dos discursos legislativos e da Emenda Constitucional de 1926 à luz do pensamento de Rui Barbosa. Viu-se que a Emenda Constitucional de 1926 concedeu um rol considerável de hipóteses de intervenção federal nos Estados. Rui Barbosa era favorável a uma reforma constitucional que regulasse a intervenção do governo federal, ainda que tenha sido um dos artífices da constituição. Rui Barbosa viu-se entre a memória agradável da Monarquia Parlamentar e a realidade abismal da República presidencial.

Abstract: The intention of this research was to analyze the political-legal narratives of the 1891 brazilian Constitution, the legislative speeches and the 1926 Constitutional Amendment in the light of Rui Barbosa's thought. It was seen that the Constitutional Amendment of 1926 granted a considerable list of hypotheses of federal intervention in the States. Rui Barbosa was in favor of a constitutional reform that regulated the intervention of the federal government, even though he was one of the creators of the constitution. Rui Barbosa found himself between the pleasant memory of the Parliamentary Monarchy and the abysmal reality of the presidential Republic.

Resumen: Esta investigación ha querido analizar las narrativas político-legales de la primera Constitución brasileña de 1891, de los discursos legislativos y de la Enmienda Constitucional de 1926 a la luz del pensamiento de Rui Barbosa. Se vio que la Enmienda Constitucional de 1926 otorgó una lista considerable de hipótesis de intervención federal en los Estados. Rui Barbosa se mostró partidario de una reforma constitucional que regulara la intervención del gobierno federal, a pesar de que fue uno de los creadores de la constitución. Rui Barbosa se encontró entre el grato recuerdo de la Monarquía Parlamentaria y la abismal realidad de la República presidencial. 
Palavras-chave: Constitucionalismo. História do Direito. Constituição de 1891. Emenda constitucional. Rui Barbosa.

Key words: Constitutionalism. Law History. 1981 Constitution. Constitutional Amendment. Rui Barbosa.

Palabras clabe: Constitucionalismo. História del Derecho. Constitución de 1891. Enmienda Constitucional de 1926. Rui Barbosa.

\section{INTRODUÇÃO}

No primeiro capítulo, inicia-se traçando em linhas gerais o momento de transição de governo brasileiro, ou seja, a mudança de Império para República, tendo como ponto de partida que tal alteração se fez por meio de um golpe sem participação pública no ano de 1889 . Nesse sentido, analisa-se de modo primevo um discurso político-econômico fundamentado nos preceitos liberais. Assim, foi construído na narrativa histórica do período republicano brasileiro, a ideia de liberalismo dentro das relações econômicas.

Deste modo, a fim de adentrar mais especificamente sobre o referido discurso, parte-se da análise de Steven Topik, este que, contrariando a narrativa historiográfica, aponta que o liberalismo republicano, nada mais era do que um discurso retórico, que na prática não conseguia sustentar-se frente as ações intervencionistas do governo federal. Sobretudo, o primeiro capitulo do presente trabalho trata de modo específico o peculiar embate travado, historicamente falando, acerca da inexistência, ou existência, para alguns, do modelo liberal na Primeira República. Pinça-se, ao longo deste tópico, ideias de expressivos autores, como Celso Furtado e Caio Prado Junior.

No capítulo que se segue efetua-se uma incursão na Constituição de 1891, a fim de demonstrar os objetivos desta que por vezes, foram contraditos pelas práticas de cunho interventivo reiteradas em todo periodo republicano, e que resultaram na Emenda Constitucional de 1926. Deseja-se, desta forma, apontar quais foram as medidas legais adotadas durante o período em questão para legitimar as intervenções econômicas.

Para isso, no terceiro capítulo, observou-se as ideias de Rui Barbosa, uma vez que este foi uma figura expressiva no âmbito político, jurídico e econômico na era republicana, e que representou, por si só, as alterações ocorridas desde 1889, tendo em vista que foi um dos criadores da Carta de 1891, mas levantou-se a favor da reforma constitucional pouco tempo depois, fato que demonstra, ainda que timidamente, que o modelo liberal instituído pela Constituição de 1891 não seria capaz de se sustentar.

Ademais, o apoio de Rui Barbosa à revisão constitucional, aponta que este, embora autodeclarado liberal, viu lacunas no modelo instituído. Conquanto, abarca-se no presente artigo, trechos e discursos do supracitado jurista que colocam em evidência os seus desacordos com o modelo político e econômico da Primeira República. Deseja-se, portanto, analisar através dos tempos as mudanças de pensamento de Rui Barbosa, a fim de evidenciar o desacordo da realidade republicana com o que fora narrado pela historiografia. 


\section{INTERVENÇÃO ECONÔMICA NA PRIMEIRA REPÚBLICA}

O período imperial brasileiro viu o liberalismo de tradição gálica acatado como ideário, ainda que recebesse, em doses nada homeopáticas, influências teóricas e práticas francesas.

Tendo como parâmetro a Monarquia orleanista, na década de 1830, desenhou-se, através das mãos de conservadores brasileiros, o modelo político caracterizado por governo unitário e parlamentar regido pela Coroa. A partir de 1867, inicia-se um movimento de contestação ao modelo, por parte de França e Inglaterra, haja vista as mudanças de caráter democrático desdobradas nestes países. Tais alterações ocorrem ao mesmo tempo que reinvindicações feitas pelas oligarquias brasileiras contra os arrochos do governo nacional. ${ }^{1}$

Deste modo, o novo Partido Liberal brasileiro, bem como a ala esquerda liberal - esta adotando o radicalismo - pediram por reformas constitucionais no processo eleitoral, pela autonomia do Judiciário, assim como pela neutralização do Poder Morador. ${ }^{2}$ Desta forma, em prol de alterações, Rui Barbosa pontuou que:

A constituição não é um Talmude, onde o texto, materialmente obedecido, exerça a menos inteligente e a mais servilizadora das tiranias; onde cada partícula encerre na sua materialidade um tesouro de sabedoria eterna, e cada traço o arcano de uma intenção divina. Esse rabinismo constitucional, esse não sei se diga, rabulismo político, que introduziria aqui as árgúcias da escola, e transformaria o parlamento nuna chacelaria de leguleios, é incompativel com as propriedades fatalmente expansivas do sistema parlamentar no seio das instituições onde uma vez o introduzem. ${ }^{3}$

Rui àquele tempo, dizia que a nação estava divorciada do governo, e que este agia em desacordo com a vontade do povo. Nesse sentido, o regime se comportava como um parasita sugando o que era de melhor da nação. Sobretudo, mesmo com entraves politicas e jurídicas durante o Império, o Brasil sofreu muitas alterações em 1889, com a queda da monarquia e o começo da Primeira República. ${ }^{4}$

Para Rui Barbosa, a prática constitucional durante o império tornou-se um ritual dotado de especificidades, com o objetivo de acobertar os problemas e enganar a população por meio de atos vazios. Desta forma, ocorreram eleições

\footnotetext{
1 Sobre este assunto importa ler Christian Edward Cyril Lynch, O momento Monarquiano: o conceito de Poder Moderador e o debate politico brasileiro do século XIX, Tese de Doutorado, Rio de Janeiro, 2007.

2 Christian Edward Cyril Lynch, "Entre o liberalismo monárquico e o conservadorismo republicano: a democracia impossivel de Rui Barbosa", Revista da Escola da Magistratura Regional Federal, Cadernos Temáticos - Justiça Constitucional no Brasil: Politica e Direito Rio de Janeiro: EMARF - TRF 2a Região, dezembro de 2010, pp. 44-45.

3 Rui Barbosa, Discursos parlamentares: Obras completas de Rui Barbosa, Vol. VI, Tomo I, Câmara dos Deputados, Rio de Janeiro, 1879.

${ }^{4}$ Rui Barbosa, Queda do Império: diário de noticias - Obras completas de Rui Barbosa, Vol. XVI, Tomo I, Ministério de Educação e Saúde, Rio de Janeiro, 1947. Prefácio e notas de Rui Barbosa em 1921.
} 
sem apuração dos votos, parlamento constituídos sem eleições ${ }^{5}$, leis sem a aprovação do parlamento. Eram feitas, portanto, liturgias e cerimônias que evidenciavam a norma, sem contar que esta já estava morta em seu interior. ${ }^{6}$

O desejo de Rui Barbosa era que a ditadura com que se inaugurou a república se apresentasse como um breve período de transição, "para a organização democrática e liberal da nova República. Naquele momento, conservadores e liberais republicanos precisavam uns dos outros para fazer prevalecer, contra o grupo positivista ortodoxo, o modelo institucional norteamericano". ${ }^{7}$

Ademais, ainda que com mudanças significativas com a transição da forma de governo e outras questões que circundam tal alteração, tem-se que a Primeira República solidificada em solo brasileiro herdou uma forte característica imperial: a produção do café. Nesse sentido, deve-se considerar que dentro das portas que se abriram com a proclamação da república, tinha-se o discurso político oficial, este baseado em uma economia liberal. 89

Nessa linha, apesar da complexidade de conceituar o liberalismo, adota-se nesse artigo, o liberalismo no sentido original, este que se explica como doutrinas que protegem a liberdade dentro do terreno econômico, político e social.

No entanto, ainda que o sistema liberal no modelo clássico laissez-faire tenha imperado no texto constitucional e em parte da literatura quanto ao tema, que se tornou persistente como fato dado para todo o contexto do período, certo é que:

A ciência econômica europeia no Brasil vinha filtrada através das faculdades de Direito, sendo transformada numa doutrina aceita sem qualquer tentativa de comparação com a realidade. Sempre que essa realidade estava longe da teoria ideal da doutrina, era isso considerado um sintoma de patologia social. ${ }^{10}$

\footnotetext{
5 O sufrágio no Império era limitado a condicionantes, ficando restrito a determinadas classes de cidadãos, sendo os resultados eleitorais frutos de interesses particulares de certos grupos (Rui Barbosa, Queda do Império: diário de notícias - Obras completas de Rui Barbosa, 1921, op. cit., p. 390).
}

${ }^{6}$ Rui Barbosa, Queda do Império: diário de noticias - Obras completas de Rui Barbosa, 1921, op. cit., p. 68.

7 Christian Edward Cyril Lynch, "Entre o liberalismo monárquico e o conservadorismo republicano: a democracia impossivel de Rui Barbosa”, op. cit., p. 48.

8 Amaury Patrick Gremaud, Das controvérsias teóricas à politica econômica: Pensamento econômico e economia brasileira no Segundo Império e na Primeira República (1840 - 1930), São Paulo, 1997, p. 177.

9 O liberalismo, desenvolvido a partir do final do século XVIII, objetivava a liberdade e estabeleceu como principal entidade da sociedade o individuo, minimizando o lugar do Estado no campo econômico, maximizando a área de atuação do indivíduo. Na seara política, o movimento incentivou a representação nos governos e nas instituições parlamentares, lutando contra o poder arbitrário do Estado e a favor das liberdades civis. Milton Friedman, Capitalismo e liberdade, Editora Ltc, Rio de Janeiro, 2014, p. 7.

10 Steven Topik, A presença do Estado na Economia Politica do Brasil: de 1889 a 1930, Record, Rio de Janeiro, 1987, p. 12. 
O problema, como bem coloca Walter Benjamin, é haver "um discurso nivelador, pretensamente universal, que se vangloria de ser a história verdadeira e, portanto, a única certa e, em certos casos, a única possivel". Com base nisso, repudia a formação de uma narrativa histórica que obedeça tão somente a interesses específicos, ${ }^{11}$ o que reforça a necessidade de refazer os percursos e deslindar elementos desprezados que resgatem as contradições eventualmente escondidas.

Para isso, acerca da história republicana brasileira é necessário compreender que o Brasil foi o primeiro país de terceiro mundo a intervir na economia, no período, em defesa de um dos produtos primários mais negociados nos mercados internacionais. Salienta-se, sobretudo, que o caminho enredado pelo Estado com o escopo de intervir cada vez mais aponta para complexidade das forças em jogo. ${ }^{12}$

Para Caio Prado Junior, no que diz respeito a economia do país, vem à tona o ideal de enriquecimento e prosperidade material e o indivíduo como sujeito livre para obter riquezas, retirando do cenário econômico o olhar condenatório à prática liberal. Desta maneira, a República rompeu o perfil conservador mantido desde o Império, e desenvolveu um novo espírito e engajamento social bem mais de acordo com a nova fase de prosperidade material que o país se encontrara. ${ }^{13}$

Logo, o Brasil deixou de maneira abrupta um sistema unitário de governo gerado pelo Império, e transformou-se em uma federação descentralizada com a concessão de maiores poderes aos Estados - as províncias do império unitário. Nesse sentido, a República instituiu flexibilidade administrativa, política e financeira aos Estados, oferecendo-lhes maior liberdade de atuação. ${ }^{14}$

Ademais, o governo tinha uma forte frente, uma vez que contava não só com militares, mas também com civis que apoiavam a nova forma de governo. Nesse sentido, era composto por Deodoro, no cargo de presidente, Rui Barbosa como Ministro da Fazenda, Campos Salles como Ministro da Justiça, Quintino Bocayuva como chefe das Relações Exteriores, Demétrio Nunes Ribeiro liderando a Agricultura, Comércio e Obras Públicas, Eduardo Wandenkolk na Marinha e Benjamin Constant (Guerra). ${ }^{15}$

Com o discurso de libertar a economia brasileira das amarras advindas do Império, o governo provisório empenhou-se em estimular o desenvolvimento, fortalecendo as relações capitalistas, através da liberação de terra, capital e mão de obra, o que passou por incremento do subsídio à vinda de imigrantes para substituir a extinta mão de obra escrava. Quanto à terra, a República abriria mão do direito sobre o subsolo e transferiria a propriedade das terras aos Estados, bem como fortaleceria o registro imobiliário. E quanto ao capital, houve

\footnotetext{
11 Jeanne Marie Gagnebin, Lembrar escrever esquecer, 34ª ed, São Paulo, 2006, p. 40. 109.

12 Steven Topik, A presença do Estado na Economia Politica do Brasil: de 1889 a 1930, op. cit., p.

13 Caio Prado Junior, História econômica do Brasil, 36 a ed, Brasiliense, São Paulo, 1970, pp. 208-209.

14 Caio Prado Junior, História econômica do Brasil, op. cit, pp. 218.

15 Luiz Carlos Delorme Prado, "A economia politica das reformas econômicas da primeira década republicana”, Revista Análise Econômica, n 39, vol. 21, março, 2003, p. 13.
} 
facilitação para operar no mercado de capitais, e constituir sociedades anônimas. ${ }^{16}$

$\mathrm{Na}$ visão de Rui Barbosa, a proclamação da república traduziu-se como a mudança "de um regime constitucional para outro, igualmente constitucional: da Monarquia à inglesa para a república à americana, de instituições já liberais para outras mais adiantadas em liberdade". ${ }^{17}$

Sobretudo, devem ser apontados três modelos de opinião que surgiram no novo molde traçado pelo advento da proclamação da República: os positivistas; os militares sem formação doutrinária - muitas vezes nominados de jacobinos, já que eram grupos exaltados; e por fim os liberais, liderados por Rui Barbosa. ${ }^{18}$

Em um primeiro olhar, percebe-se que a política financeira foi a base do programa econômico do período, em especial como resposta às crises, o que levou a intervenção no mercado do café, das ferrovias e nas indústrias. Para os funcionários do governo, este não deveria intervir na produção, mas assegurar circulação de produtos e de capital, pelo que as ações do Estado seriam na taxa cambial, disponibilidade de recursos e rede bancária, já que estes eram os elementos que geravam a distribuição de riqueza, influenciavam o crédito, os investimentos estrangeiros, controlavam a atividade econômica e o custo de vida. ${ }^{19}$

O Brasil fora moldado de acordo com suas funções na economia mundial de produtos primários, e é nesse sentido que as produções variaram no tempo e espaço, mas determinaram as relações sociais e o crescimento econômico. Sendo assim, "as divisas produzidas com essas exportações pagavam as importações necessárias para a implantação da infraestrutura e capacidade industrial do Brasil". 20 Outrossim,

Se a descentralização republicana deu maior flexibilidade político-administrativa ao governo no campo econômico, em beneficio dos grandes interesses agrícolaexportadores, por outro lado a ascensão política de novos grupos sociais, de rendas não derivadas da propriedade - facilitada pelo regime republicano - veio reduzir substancialmente o controle que antes exerciam aqueles grupos agrícolaexportadores sobre o governo central. Tem início assim um período de tensões entre os dois níveis de governo - estadual e federal - que se prolongará pelos primeiros decênios do século atual. ${ }^{21}$ 41.

16 Steven Topik, A presença do Estado na Economia Politica do Brasil: de 1889 a 1930, op. cit., p.

17 Rui Barbosa, Campanhas jornalisticas: Império: 1869-1889 - Obras Seletas de Rui Barbosa, Vol. 6, Rio de Janeiro, 1956, p. 269.

18 Antonio Paim, História do liberalismo brasileiro, Editora Mandarim, São Paulo, 1998, p. 123. 38.

19 Steven Topik, A presença do Estado na Economia Politica do Brasil: de 1889 a 1930, op. cit., p. 16.

20 Steven Topik, A presença do Estado na Economia Politica do Brasil: de 1889 a 1930, op. cit., p.

21 Celso Furtado, Formação econômica do Brasil, $17^{\mathrm{a}}$ ed, Companhia editora nacional, São Paulo, 1980, p. 172-173. 
Entretanto, as atividades que derivam do novo sistema econômico, baseado na mão de obra assalariada, apresentaram diversos problemas. Um dos déficits instaurados era a não adaptação ao padrão ouro, que era, por assim dizer, a pedra de toque da economia internacional22. Destarte, por depender substancialmente de exportações, a economia deparava-se, por vezes, a oscilações abruptas no mercado econômico.

Não obstante, a crise do café deu lugar a propostas diversas, tais como limitar o domínio do mercado por exportadores estrangeiros; planos para reduzir as produções ou para aumentar a demanda; e por fim, planos para reduzir os custos dentro do processo de produção. ${ }^{2324}$

Torna-se evidente, portanto, que o Brasil era, na Primeira República, um país monocultor, tendo sua renda fundamentada na exportação de um produto principal, sem grande desenvolvimento mecânico, e produzindo poucas coisas em processos repetitivos. Em uma perspectiva geral, o Brasil era, no tempo da República, um país de típica economia colonial, dependendo de participação externa para manter seu mercado aquecido e equilibrado.

$\mathrm{E}$ ao redor das atividades econômicas, ainda que pareça haver a predominância dos interesses dos cafeicultores, confrontavam-se diversas forças, como os intermediadores, os financiadores, os produtores, os comerciantes, os compradores.

Entretanto, o Estado demonstrava-se despreparado para articular tais inconstâncias no campo econômico. Com face ao exposto, Celso Furtado pontua que a crise econômica se apresentava como um cataclismo, de fora para dentro, uma vez que a economia era dependente das exportações de produtos primários. ${ }^{25}$

Não obstante, a fim de proteger o café e fortalecer a economia nacional, variáveis métodos foram instituídos, sendo estes de cunho interventivo. Nesse hiato, tais atuações estatais foram feitas por mecanismos monetários e financeiros, controlados pela forte mão do Estado. ${ }^{26}$

Nesse hiato, para tornar a supracitada colocação mais tangivel, pinça-se o exemplo do Convênio de Taubaté em 1906, no qual foram estabelecidos os fundamentos que norteariam a politica de valorização do produto. ${ }^{27}$

22 Celso Furtado, Formação econômica do Brasil, op. cit., p. 155.

${ }^{23}$ Steven Topik, A presença do Estado na Economia Politica do Brasil: de 1889 a 1930, op. cit., p. 75 .

${ }^{24}$ No final do século houve uma queda brusca no preço internacional do café, devido a uma combinação de fatores: a crise de 1893 mundial, que implicava em decréscimo da demanda por um produto não exatamente essencial; a manipulação e poder dos exportadores estrangeiros, que passaram a atravessar os comissionários, mas também o excesso de produção advindo da corrida ao plantio de novos pés. Tais considerações encontram-se em Steven Topik, A presença do Estado na Economia Politica do Brasil: de 1889 a 1930, op. cit., p. 76.

${ }^{25}$ Celso Furtado, Formação econômica do Brasil, op. cit., p. 166.

26 Maria Elizabeth Guimarães Teixeira Rocha, "A intervenção do Estado brasileiro e a politica oligárquica na república velha”, Revista de Informação Legislativa, a. 32, n 126 abr./jun. Brasília, 1995.

27 Havendo desequilíbrio entre oferta e demanda do café, o governo compraria, através de empréstimos estrangeiros, os produtos excedentes no mercado, e para quitar a dívida estrangeira 
Fato é que embora tenha havido uma intervenção para auxilio do café, quase todas as pautas do tratado de Taubaté ou não foram implementadas ou foram paulatinamente abandonadas, e a Primeira Guerra Mundial obrigou o governo a novamente intervir, só que desta vez mais rapidamente. ${ }^{28}$

Mas as dificuldades advindas da guerra revelaram também as fragilidades de uma economia toda sedimentada na participação estrangeira, o que levou a uma maior intervenção no sistema financeiro por meio do Banco do Brasil. Logo, a presença do estado no sistema financeiro manteve-se após o fim da Guerra, fortalecendo-se bancos nacionais e controlando os estrangeiros, ${ }^{29}$ ainda que tenha persistido a preponderância do capital inglês mesmo após o conflito. ${ }^{30}$

A fim de justificar a intervenção do Estado nas relações econômicas, Maria Elizabeth Rocha afirma que o mercado se nutre do intervencionismo, e ações desse cunho são necessárias para corrigir os desequilíbrios do liberalismo e preservar o mercado. ${ }^{31}$ O que para Steven Topik não passa de um argumento dialético para conceder carta branca para que o Estado atue sem restrições.

Conquanto, para Celso Furtado as politicas de defesa e valorização do café funcionaram "até fins do terceiro decênio deste século", quando a crise mundial de 1929 foi fator substancial para transformar esse cenário. De 1925 a 1929 o desenvolvimento foi quase de $100 \%$ (cem por cento), o que demonstra a expressiva quantidade de plantações de novos arbustos de café, mas com estabilidade dos quantitativos de exportação. E é nesse desequilíbrio entre oferta e demanda que as exportações em 1927 a 1929 conseguem consumir apenas 2/3 quantidade produzida, quando a crise de 1929 causam profunda desvalorização do produto. ${ }^{32}$

Nesse fulcro, muitas medidas foram abarcadas pela politica da Primeira República, como por amostra a desvalorização cambial. Nesse sentido, é de percepção imediata o duplo efeito dessa providência sobre a ótica orçamentária do país: "a queda da receita em função da diminuição das importações e aumento das despesas em moeda nacional decorrente do aumento do valor da divida e de seus encargos cotados em mil réis". ${ }^{33}$

um imposto em ouro sobre cada saca de café seria instituído. Por outro lado, a fim de restabelecer o equilíbrio econômico a longo prazo, os governos estaduais dos Estados produtores deveriam desestimular a expansão de novas plantações. Celso Furtado, Formação econômica do Brasil, op. cit., p. 179. 88 .

28 Steven Topik, A presença do Estado na Economia Politica do Brasil: de 1889 a 1930, op. cit., p.

${ }^{29}$ Steven Topik, A presença do Estado na Economia Politica do Brasil: de 1889 a 1930, op. cit., p. 59.

30 Edgard Carone, A República Velha: Instituições e classes sociais, op. cit, p. 127.

31 Maria Elizabeth Guimarães Teixeira Rocha, "A intervenção do Estado brasileiro e a politica oligárquica na república velha”, op. cit., p. 212.

32 Celso Furtado, Formação econômica do Brasil, $17^{\mathrm{a}}$ ed, Companhia editora nacional, São Paulo, 1980, p. 181.

33 Amaury Patrick Gremaud, Das controvérsias teóricas à politica econômica: Pensamento econômico e economia brasileira no Segundo Império e na Primeira República (1840 - 1930), op. cit., p. 182 . 
Entende-se que a intervenção foi um mecanismo encontrado para dar cabo aos problemas presentes no período republicano. Nessa esteira, era encarada como um mecanismo de defesa da economia brasileira frente às dificuldades que a caracterizavam.

A intervenção do Estado nas relações de trabalho, igualmente uma forma de intervenção econômica, tem seu início marcado na homologação do Tratado de Versalhes em 1919 pelo Congresso Nacional. Até o referido ato, João Tristan Vargas $^{34}$ sustenta que o molde liberal estava a todo vapor na república, prevalecendo como modelo a ortodoxia não-intervencionista.

No entanto, importa considerar que neste mesmo ano institui-se no país a primeira legislação de cunho social, a lei de acidentes do trabalho, e nos anos seguintes haveria um constante movimento de criação de leis federais para o setor, como a criação das caixas de aposentadorias e pensões, de 1923, e a lei de férias, de 1926. Os princípios que nortearam a federalização legislativa na área após a Revolução de 1930 já estavam todas enunciadas nos discursos legislativos, nas primeiras leis do tema e nos textos dos autores que se dedicaram à matéria. ${ }^{35}$

No tocante a intervenção no setor industrial da Primeira República, pode-se notar a presença do Estado antes mesmo dos anos 30, afirmação contrária ao que geralmente é descrito na literatura econômica brasileira. Desta forma, na visão de Claudilei Rocha, a participação ativa do Estado no desenvolvimento industrial se iniciou, ainda que timidamente, depois da Primeira Guerra Mundial. 36

Uma medida de incentivo à indústria foi a chamada Lei dos Similares. Por essa lei, ficou expressamente proibida a concessão de isenção às importações de produtos que tivessem similares no país, seguindo a nova lei n. ${ }^{\circ} 8.592$, de 08 de março de 1911. Sobretudo, no ano de 1925 foi criada uma lei que garantia isenções tarifárias para aquelas firmas que possuíssem o registro dos seus produtos como similares. Logo, por conta dessa medida de cunho legislativo, houve um crescimento significativo no registro de produtos. ${ }^{37}$

$\mathrm{Na}$ concepção de Celso Furtado, manter o equilíbrio e a média dos preços em um baixo padrão era fator substancial para que os produtores do Brasil mantivessem o semimonopólio no país. ${ }^{38}$ Todavia, da maneira como foi instituída e posteriormente seguida, tais manutenções desencadearam uma forte crise econômica cafeeira na Primeira República. Nessa linha

34 João Tristan Vargas, Ordem liberal e relações de trabalho na Primeira República, Tese de doutorado em História, Instituto de filosofia e Ciências Humanas, Unicamp, 1999, p. 3.

35 Neste sentido, cf. Fernanda Cristina Covolan, Novos Tempos, velhos problemas: legislação sobre a questão social na Primeira República. Tese de doutorado em Direito Politico e Econômico. Universidade Presbiteriana Mackenzie, SP, 2019.

36 Claudinei Rodrigues da Rocha, ROCHA, Estado e indústria nas décadas de 1920 e 1930: uma análise da participação estatal no processo brasileiro de industrialização. 2003. Dissertação de mestrado em economia, Universidade Estadual de Campinas, SP.

37 Claudinei Rodrigues da Rocha, Estado e indústria nas décadas de 1920 a 1930: uma análise da participação estatal no processo brasileiro de industrialização, op. cit., p. 17.

38 Celso Furtado, Formação econômica do Brasil, op. cit., p. 183. 
Em contrapartida, Gremaud ${ }^{39}$ defende que a intervenção econômica realizada pelo governo visava, ainda que de modo genérico, proteger a economia brasileira frente as crises externas, nem sempre com resultados adequados. Para o autor, a intervenção no mercado de café, a política creditícia e monetária, e as politicas industrializantes pareciam indicar a busca do Estado em uma maior proteção macroeconômica, para frear as depressões externas que se alastravam no mercado nacional.

Mas como pontua $\operatorname{Topik}^{40}$, a intervenção que se verificou não pode ser atribuida apenas ao poder político dos cafeicultores no país, já que países vizinhos em situação política semelhante não viram intervenção semelhante. Nesse interim, a própria natureza do café, o monopólio do Brasil sobre o mercado mundial deste mesmo produto, a forte mão da burguesia brasileira e a concorrência estrangeira, acabou por colocar em evidência as ações do Estado na esfera financeira.

Torna-se evidente, portanto, que houve progressiva mas intencional e persistente intervenção governamental no período republicano E é nesse sentido que se pode afirmar que o liberalismo era violado repetidamente na prática, enquanto proclamado como preceito nos discursos politicos na era republicana brasileira.

Assim, ao analisar de modo superficial a história percorrida durante os quarenta anos de Primeira República, desavisadamente pode alguém ser levado a pensar em um forte liberalismo perpassando o novo modelo de governo.

Não é surpresa conceber, portanto, que o liberalismo não conseguiu transpassar as barreiras do texto constitucional, tendo como exemplo prático as intervenções para regulação da moeda, da imigração e nas políticas de valorização do café, para além das intervenções várias.

Durante toda a Primeira República, o argumento era dialético: as intervenções tornavam-se necessárias para acabar com distorções no mercado e para permitir o livre jogo das forças de oferta e demanda ${ }^{41}$. As intervenções eram consideradas momentâneas ou parciais e aplicáveis principalmente ao café em face do seu peso para a economia.

Deste modo, as alterações decorrentes do século XIX, distante de demonstrar a quebra da ordem politico-econômica, resultou na conservação de aparências liberais, tendo como base a Constituição, sendo esta relativizada e deteriorada por normas infraconstitucionais, práticas e costumes. ${ }^{42}$

Manteve-se a ideologia do laissez-faire, mas esta foi mais flexivel do que se pensa. Nesse sentido, no período republicano é inquestionável a utilização de

39 Amaury Patrick Gremaud, Das controvérsias teóricas à politica econômica: Pensamento econômico e economia brasileira no Segundo Império e na Primeira República (1840 - 1930), op. cit., p. 254. 110 .

40 Steven Topik, A presença do Estado na Economia Politica do Brasil: de 1889 a 1930, op. cit., p. 110 .

41 Steven Topik, A presença do Estado na Economia Politica do Brasil: de 1889 a 1930, op. cit., p.

42 Fernanda Cristina Covolan, Novos tempos, velhos problemas: legislação sobre a questão social na Primeira República, op. cit., p. 84. 
empréstimos como mecanismo para livrar o Estado de crises, o que aponta para a prática de amortização das dívidas a vencer. Contudo, o posicionamento de Rui Barbosa é contrário a tais medidas emergenciais, e aconselha que o governo fuja da recepção de novas dividas por meio dos empréstimos solicitados. Nitidamente, o que ocorre é o oposto, visando a supressão dos déficits e correção de problemas nas finanças do país. ${ }^{43}$

Assim, a progressiva ampliação do espaço do Estado na economia se tornaria cada vez mais contraditória com a ideologia defendida, e para o autor a Revolução de 1930 viria justamente para adequar ideologia e realidade da política oficial. ${ }^{44}$ Uma vez que, ao observar a era republicana, ficava patente que a ideologia liberal adotada deixava de se estender às politicas econômicas do país.

Voltando a ideia centralizada nos discursos dos politicos republicanos, no que diz respeito a não intervenção econômica, percebe-se que tal ideário conservador não passava de uma estratégia, sustentada em um sistema discursivo, para controlar de modo mais efetivo o poder federal, a fim de dificultar a atuação deste no sistema econômico e interferir a regulamentação sobre, até mesmo, questões sociais.

\section{LEGISLAÇÃO E INTERVENÇÃO ECONÔMICA NA PRIMEIRA REPÚBLICA}

Se na primeira parte deste trabalho objetivou-se fazer uma breve digressão sobre a construção teórica sobre a economia liberal da Primeira República, demonstrando-se ser inadequado referir o período como isento de medidas intervencionistas na economia, aqui importa compreender quais os meios legais, em todos os graus hierárquicos, de que se serviu o governo de então para alcançar seus objetivos.

A República, uma vez proclamada, implicara em mudanças mais significativas do que apenas o afastamento da casa imperial: as elites das Províncias, que se tornariam os Estados, desejavam mais controle político local, e menor interferência federal, o que teria aproximado os ideólogos republicanos a algum encantamento com o modelo americano.

Neste cenário, Rui Barbosa foi o primeiro Ministro da Fazenda do período republicano, e sua principal medida foi a Lei Bancária, de janeiro de 1890. A referida lei foi uma medida que representou o restabelecimento do primeiro projeto datado no ano de $1888 .{ }^{45}$

Como referido, era um tempo de transição. Ainda exercendo sua função, em 1891 Rui Barbosa precisou conciliar diversos e conflitantes interesses: as necessidades do governo e necessidades do mercado; interesses de republicanos e interesses de monarquistas.

43 Edgard Carone, A República Velha: Instituições e classes sociais, Editora Pensamento S/A, São Paulo, 1970, p. 135.

${ }^{44}$ Steven Topik, A presença do Estado na Economia Politica do Brasil: de 1889 a 1930, op. cit., p. 189.

45 Amaury Patrick Gremaud, Das controvérsias teóricas à politica econômica: Pensamento econômico e economia brasileira no Segundo Império e na Primeira República (1840 - 1930), op. cit., p. 188. 
Não obstante, Rui iniciou sua caminhada ao lado do idealismo e da doutrina, atingindo seu auge nos anos do Governo Provisório, quando como ministro do Estado cooperou para a formação de um projeto de república solidificado no modelo constitucional liberal-democrático.

Convocada a Assembleia Constituinte, composta por conservadores, liberais e positivistas, as discussões saudaram majoritariamente o anteprojeto do governo, da lavra de Barbosa. Entretanto, algumas propostas expressivas não passaram pelo crivo dos constituintes, apontando-se como exemplo questões sobre a unidade do Judiciário e o parlamentarismo.

No ano anterior, para a gestão do país, vigeu uma Constituição Provisória que tinha por escopo retirar das mãos do Estado a liberdade pertencente ao corpo social, bem como remover a influência preponderante exercida pela moldura intelectual francesa. Nesse sentido, algumas medidas foram tomadas, como o término da vitaliciedade do Senado (artigo 31), autonomia de um Poder Judiciário (artigo 53), alteração do sistema de governo (artigo $1^{\circ}$ ), mudança do parlamentarismo para o presidencialismo (artigo 41) e formação de um Supremo Tribunal (artigo 55). ${ }^{46}$

Apartando-se do Governo Provisório, perto da promulgação do texto constitucional republicano, Rui Barbosa chegou ao fim de sua jornada normativa em busca da democracia liberal, e viu-se mediante um novo desafio: aplicar, dentro da realidade republicana, a nova Carta, e desenvolver, dentro das inquestionáveis limitações, os princípios ali estabelecidos, ensinando as elites do periodo as frentes de ações das instituições livres. ${ }^{47}$

Este texto, no entanto, não derivou apenas do engenho de Rui Barbosa, já que há indicativos de que houve uma importante influência da Constituição argentina no texto nacional. De fato, Christian Lynch refere que Quintino Bocaiuva e Campos Sales, uma vez nomeados ministros das Relações Exteriores e da Justiça do Governo Provisório, instituíram uma comissão insigne a fim de elaborar um anteprojeto constitucional que, tendo como base o modelo argentino, retirasse o que fosse de melhor do modelo norte-americano. Sendo assim, o primeiro documento da ordem jurídica-política da era republicana recém fundada trouxe em seu bojo claros reflexos da supracitada organização política. ${ }^{48}$

Para Oliveira Vianna ${ }^{49}$, crítico contundente do sistema político do período, as inspirações, as inspirações estrangeiras injetadas na realidade politico-jurídica brasileira não se enquadrariam de maneira adequada aos acontecimentos dentro

46 Constituição da República dos Estados Unidos do Brasil. Rio de Janeiro, Congresso Nacional, 1891.

47 Rui Barbosa, Ruinas de um Governo: o governo Hermes, as ruinas da Constituição, a crise moral, a justiça e manifesto à Nação, Prefácio e notas de Fernando Néry. Guanabara, Rio de Janeiro, 1931, p. 140.

48 Christian Edward Cyrill Lynch, Da monarquia à oligarquia: História institucional e pensamento politico brasileiro (1822 - 1930), op. cit., p. 107.

49 Para o autor, não há de se falar em um sistema fundamentado no modelo liberal sem que haja uma sociedade liberal. Deste modo, importa ler Instituições políticas brasileiras, vol. II, EDUFF, Niterói, 1987. 
do regime republicano do Brasil, gerando instabilidade e inconsistência ao governo, acarretando, assim, problemas na democracia e na formação social. 50

Deste modo, parece que para o jurista supracitado, a Constituição republicana, decalcada de modelos estrangeiros, era insustentável e incapaz de suprir as necessidades da população, haja vista a total incompatibilidade entre realidade e norma.

Ainda é Lynch que, analisando a participação de Rui Barbosa nos tempos em questão, afirma que o Ministro da Economia, e jurista, estava descontente com as limitações traçadas na prática e no ideário liberal perante a monarquia parlamentar. ${ }^{51}$ Nesse hiato, Rui Barbosa instituiu uma promoção doutrinária e idealista que teve como pináculo o Governo Provisório da República, no qual, nomeado ministro, elaborou um projeto de república que almejava a democracia e prezava pelo ideário liberal, somando-se aos desejos da população, que dizia representar. Ademais, Rui Barbosa esbarrou-se com o cenário autoritário dos primeiros anos da república, logo após ao democratismo jacobino e o conservadorismo das oligarquias. Todavia, foi esse conjunto de experiências que fizeram com que Rui Barbosa amadurecesse e ganhasse nome no âmbito político.

Nesse sentido, convém citar que houve uma forte resistência para convocar a Assembleia Constituinte, o que de fato só foi possivel pela força e persistência de Rui Barbosa, este que lutava pela valorização da questão constitucional e democratização da Primeira República. ${ }^{52}$ Veja-se que, comparada a diversos países, a nova República sediada no Brasil era, até o fim do século XIX, a república com participação política mais circunscrita. ${ }^{53}$

A Constituição de 1891 estabeleceu como sistema de governo o presidencialismo do Poder Executivo. Em contrapartida, concedeu maiores competências aos Estados brasileiros, ficando demonstrado o desejo de descentralização dos poderes da União. Para Antonio Paim, tais colocações no texto constitucional republicano eram basicamente antagônicas, uma vez que não condiziam nem com a própria Constituição, tampouco com as práticas republicanas. 54

Federações clássicas, pinçando como exemplo Suiça e Estados Unidos, surgiram através da autonomia conquistada por meio da independência territorial. Entretanto, a federação brasileira desdobrou-se de modo adverso, ou seja, os novos Estados estabelecidos pela Constituição de 1891 não haviam sido autônomos ou independentes, o que está repetido resultou na incapacidade de estes articularem de modo adequado os poderes adquiridos.

50 Francisco José de Oliveira Vianna, O idealismo da Constituição, $2^{a}$ ed, Editora Companhia Editora Nacional, São Paulo, 1939, p. 15.

51 Christian Edward Cyrill Lynch, Da monarquia à oligarquia: História institucional e pensamento politico brasileiro (1822 - 1930), op. cit., pp. 201-202.

52 Antonio Paim, História do liberalismo brasileiro, op. cit., pp. 123-124.

53 Christian Edward Cyrill Lynch, Da monarquia à oligarquia: História institucional e pensamento politico brasileiro (1822 - 1930), $1^{\text {a }}$ ed, Alameda Casa Editorial, São Paulo, 2014, p. 113.

54 Antonio Paim, História do liberalismo brasileiro, op. cit., p. 128. 
Como consequência, esses poderes, que deveriam pertencer de modo primevo a estes, começaram a ser, ainda que timidamente, recolhidos pelas mãos da União, com o passar do tempo. ${ }^{55}$

Nesse hiato, ao analisar a constituição republicana, depara-se com o artigo $6^{\circ}$, que previa exceções que permitiam a intervenção do Governo federal nos negócios dos Estados: para impedir invasão estrangeira ou invasão de um Estado em outro, para proteger a forma republicana federativa, para restituir a ordem e tranquilidade nos Estados, com a requisição dos respectivos Governos e para garantir a execução das leis e sentenças federais. ${ }^{56}$

Sobre o aspecto jurídico-constitucional depois da alteração da forma do Estado, sendo republicano e federativo, é importante destacar o surgimento da discriminação das rendas públicas. O que acontece de fato é a mudança de um Estado unitário, centralizado, para o seu oposto e, é nesse cenário que "a discriminação de rendas aparece como o punctum pruriens de todo o sistema, pois é a partir da autonomia financeira que se erige a autonomia politica e a própria federação". ${ }^{57}$

Como visto no parágrafo anterior, a repartição de poderes também foi novidade no período republicano, isso porque a Constituição de 1891 transferiu vários poderes antes colocados na mão do poder central, para os estados, como o imposto sobre exportação, que antes era dividido com o governo federal. Além disso, com o novo texto constitucional tornou-se viável adquirir empréstimos sem aquiescência e autorização federal, assim como a concessão de direitos sobre terras do território, até mesmo as devolutas. Com tais alterações os estados do centro-sul ganharam expressivos benefícios, em especial São Paulo, que viu sua receita decuplicar-se entre 1880 e 1895.58

Nessa esteira, o corpo constitucional construído em 1891 fortaleceu sobremaneira o grupo liberal. Desta forma, ao longo das três primeiras décadas republicanas, a doutrina política oficial corresponde ao liberalismo.

No entanto, em que pese a previsão constitucional, o começo da república revelou dificuldades políticas diante das disputas constantes entre as forças regionais dos Estados, o que foi acertado por meio da Politica dos Governadores, pela qual formava-se um acordo de suporte a grupos predominantes desde que a União deixasse a política dos Estados sem interferência. 59

Tratando-se de autoritarismo pode-se considerar que o sistema politico da Primeira República em sua natureza já revela a subordinação de determinadas classes e a inexpressividade - no que diz respeito a força - da classe média. Tal fraqueza fica mais bem demonstrada ao passar os olhos sobre o sistema eleitoral previsto na Constituição de 1891, que ainda que aparentemente democratizante,

\footnotetext{
55 Antonio Paim, História do liberalismo brasileiro, op. cit., p. 129.

56 Constituição da República dos Estados Unidos do Brasil, op. cit.

57 Celso Ribeiro Bastos e Maria Garcia, et al., As constituições brasileiras: análise histórica e propostas de mudança, Editora Brasiliense, $1^{a}$ ed, São Paulo, 1993, p. 18.

58 Steven Topik, A presença do Estado na Economia Politica do Brasil: de 1889 a 1930, op. cit., p. XXX (Prefácio).

${ }^{59}$ Andrei Koerner. Judiciário e cidadania na constituição da república brasileira (1841-1920). $2^{a}$ ed. Curitiba: Juruá, 2010
} 
qualificava cerca de $6 \%$ da população para votar ${ }^{60}$. Aliado a esta limitação estava o coronelismo, por meio do qual proprietários de fazendas, às vezes comerciantes e industriais ao mesmo tempo, usavam o poder econômico e relações clientelistas para garantir seus interesses eleitorais.

Questionados sobre a grande deficiência no que diz respeito a representação, quase que em um reflexo natural, republicanos justificavam como razão do problema a "herança maldita" da monarquia, cuja venenosa cultura de manipulação eleitoral fazia eco nas práticas republicanas. ${ }^{61}$

$\mathrm{Na}$ verdade, ainda que os líderes politicos tivessem como hábito homenagear os ideais politicos liberais, o que se via era a realidade, a ideologia dominante de um país recém-saído de um sistema monárquico cuja economia se fundava em modo de produção escravocrata, pelo que difícil imaginar aptidão para procedimentos democráticos. E é sobre esse prisma que Steven Topik ${ }^{62}$ afirma que o liberalismo instituído no Brasil não era calcado em uma doutrina oposicionista de uma burguesia urbana pelejando para ganhar poder, tal como aconteceu na Europa, mas sim um discurso da classe dominante agrária, em que os ideais liberais pelos* quais se interessavam eram o direito de propriedade, laissez-faire e livre comércio, mas não de eleições democráticas.

Como se vê, a vida republicana não fez com que houvesse maior representação nas campanhas e votações eleitorais, parecendo, na verdade, que as feridas abertas provocadas pelo sistema eleitoral da monarquia eram iguais ou até menores que estas vividas na república. ${ }^{63}$

A Constituição Federal de 1891 instituiu que as relações de trabalho deveriam se reger de acordo com as suas vontades, sustentadas pelo que foi acordado entre as partes através deste contrato bilateral. Fica demonstrado, portanto, que o Estado não poderia intervir em tais relações, somente em casos excepcionais, como para garantir a ordem.

Nesse sentido, Rui Barbosa pontua que pairava uma dúvida das autoridades acerca da sua motivação para a revisão constitucional, não se sabia se ele desejava mudar a Constituição, a fim de coibir a formação de contratos bilaterais, ou se estava querendo fazer com que o Estado interferisse em "seara alheia" por meio de leis na questão social. ${ }^{64}$

Como principal redator da Constituição Federal de 1891, Rui Barbosa imaginava um regime mais amplo e plural, sustentado pela moralidade e democracia. Todavia, a ala conservadora acabou por transformar o regime em algo fraudulento e monopolístico. Para ele, o direito era fundamento da ordem

\footnotetext{
19.

${ }^{60}$ Steven Topik, A presença do Estado na Economia Politica do Brasil: de 1889 a 1930, op. cit., p.

${ }^{61}$ Christian Edward Cyrill Lynch, Da monarquia à oligarquia: História institucional e pensamento politico brasileiro (1822 - 1930), op. cit., p. 155.

62 Steven Topik, A presença do Estado na Economia Politica do Brasil: de 1889 a 1930, op. cit., p. 20.

63 Christian Edward Cyrill Lynch, Da monarquia à oligarquia: História institucional e pensamento político brasileiro (1822 - 1930), op. cit., p. 156.

${ }^{64}$ Rui Barbosa, Campanha presidencial: Obras completas de Rui Barbosa, Vol. XLVI, Tomo I. Rio de Janeiro, 1919, pp. 108-109.
} 
legítima, capaz de limitar a atuação política para assegurar a liberdade individual. Com efeito, Rui Barbosa acreditava na divisão equilibrada dos poderes políticos, na valorização do Poder Judiciário, na liberdade como mecanismo necessário para que o bem (o direito) vencesse o mal (autoritarismo político), e é nesse sentido que, por contraste, ele aponta as características do mau governo. De modo específico, Rui Barbosa associa o mau governo à imoralidade, injustiça, arbitrariedade, violência, opressão e quebra de direitos. ${ }^{65}$

Nesse interim, a própria Constituição de 1891 previu a possibilidade de ser emendada, haja vista o seu artigo 90 que dispôs que "a Constituição poderá ser reformada, por iniciativa do Congresso Nacional ou das Assembléias dos Estados" e instituiu, nos parágrafos subsequentes as regras de atuação do poder constituinte derivado, assim como o quórum para aprovação $\left(\S \S 1^{\circ}, 2^{\circ}\right)^{66}$. Outrossim, no $4^{\circ}$ parágrafo 67 do mesmo artigo pretendeu-se limitar o poder reformador no tocante aos objetos para deliberação, proibindo levar ao Congresso projetos que visassem dar cabo a forma republicano-federativa, ou a igualdade da representação dos Estados no Senado. 68

Como se viu, a possibilidade de emenda constitucional estava presente na própria Constituição. Sobretudo, revela-se importante destacar que esse tema levantou discussões acaloradas nas reuniões da Assembleia Constituinte em 1890 , tendo em vista que alguns pontos levantados resultaram em confrontos de diferentes concepções politicas. A fim de aclarar o pensamento anteriormente demonstrado, importa destacar três pontos de divergência sobre o estabelecimento da revisão constitucional: quórum para aprovação, limites da reforma e as matérias que poderiam ser objeto de revisão. ${ }^{69}$

Deste modo, observa-se durante a Primeira República uma insatisfação com a letra constitucional, que em muito era contrariada nas ações republicanas. Nesse sentido, a possibilidade estabelecida no artigo $90^{\circ}$ da Constituição tão criticada, concedia oportunidade para muitos que, insatisfeitos com a primeira constituição republicana do país, desejavam reformá-la.

No que se refere ao modelo econômico, tem-se que muitos países que tinham uma estrutura politico-constitucional passaram por muitas agitações antiliberais

65 Christian Edward Cyrill Lynch, Da monarquia à oligarquia: História institucional e pensamento politico brasileiro (1822 - 1930), op. cit., p. 93.

66 Tendo como base a assentada premissa, os primeiros olhares para a revisão constitucional ocorreram logo depois da instauração da república em 1889, quando Leopoldo Bulhões, dentro da Assembleia Constituinte, levou à pauta a necessidade de reformar alguns artigos da Constituição de 1891.

67 "O último parágrafo do art. 90 do projeto proposto pelo Governo Provisório limitava o poder constituinte derivado, excluindo da possibilidade de reforma o art. 1 da Constituição, que estabelecia o sistema republicano federativo no país e a igualdade de representação dos Estados no Senado Federal. Essa restrição gerou algumas divisões no seio da Constituinte, já que muitos consideravam-na uma ofensa ao princípio de soberania da nação" (Priscila M Pivatto, Discursos sobre o Estado de Sítio na Primeira República Brasileira: Uma abordagem a partir das teorias de linguagem de Mikhail Bakhtin e Pierre Bourdieu, p. 124).

68 Constituição da República dos Estados Unidos do Brasil, op. cit.

69 Priscila M Pivatto, Discursos sobre o Estado de Sítio na Primeira República Brasileira: Uma abordagem a partir das teorias de linguagem de Mikhail Bakhtin e Pierre Bourdieu. Dissertação de Mestrado, Rio de Janeiro, 2006, p. 124. 
depois da guerra de 1914 a 1919. Pinça-se como exemplo a vitória do fascismo em 1922-1923 por Mussolini, a agitação na Alemanha provocada pelo nazismo em busca de poder, e o governo totalitário corporativista de Portugal. Essas convulsões ecoaram no Brasil, ainda que poucos entendessem os objetivos e ideologias dos movimentos europeus, fazendo com que ainda que não compreendessem os alvos traçados nas ações europeias, desejassem mudanças substanciais na estrutura constitucional como remédio a antigas chagas. ${ }^{70}$

Nessa esteira, a República brasileira expôs desde o século 19, e ainda mais fortemente no século 20, as fragilidades e problemas do seu modelo econômico ${ }^{71}$. Sendo assim, para Aliomar Baleeiro ninguém mais aspirava expectativas sobre a República, tampouco sobre o cumprimento da Constituição Federal de 91, isso porque esta era desconsiderada pelo Congresso Nacional e pelo sistema eleitoral. ${ }^{72}$

E é por conta dessas fragilidades e problemas enfrentados pela Primeira República que se pode considerar a presença do espírito do revisionismo dentro de muitos, o que implica dizer que a ideia de promover uma revisão constitucional esteve sempre vivida no âmbito político do período republicano. ${ }^{73}$

\section{REVISÃO CONSTITUCIONAL E A FIGURA DE RUI BARBOSA}

Retratado por muitos como alguém franzino e fraco fisicamente ${ }^{44}$, Christian Lynch $^{75}$ pondera que Rui Barbosa era único no que respeito a força, agressividade na oratória e austeridade na defesa pelo radicalismo e na luta em busca do modelo liberal. Pontua, sobretudo, que "sua anglofilia exagerada" deu base às severas criticas levantadas contra as instituições do Império. Rui negava que a relativa autonomia imperial era necessária para libertar o país das amarras oligárquicas e da tirania do unipartidarismo, não a vendo como elemento suficiente para garantir um sistema representativo no atrasado Brasil.

Nessa esteira, Fernando Néry, ao escrever um prefácio para uma das obras de Rui Barbosa, o descreve como um "mocinho, trinta anos, pequena estatura, magrinho, testa ampla, - físico ingrato para aquele que se iria tornar o maior tribuno brasileiro. A inteligência, a cultura, a coragem, em organismo tão mofino, supririam, porem, o que lhe negara em dotes físicos a natureza madrasta"76.

70 Aliomar Baleeiro, Coleção Constituições brasileiras: 1891, op. cit., p. 46.

71 Fernanda Cristina Covolan, Novos tempos, velhos problemas: legislação sobre a questão social na Primeira República, op. cit., p. 72.

72 Aliomar Baleeiro, Coleção Constituições brasileiras: 1891, op. cit., p. 45.

73 Eduardo Junqueira, Reforma da constituição de 1891, CPDOC, pp. 1-2.

74 Essas características eram comumente citadas, o que pode ser visto nas bibliografias de autores como Afonso Cesar Junior, Oito anos de parlamento, Brasília, 1981; Gilberto Freyre, "Introdução" in Joaquim Nabuco, Série perfis parlamentares, $2^{a}$ ed, Brasília, 2010; Fernando Néry "Introdução" in Rui Barbosa, Discursos parlamentares: Obras completas de Rui Barbosa, Vol. VI, Tomo I. Câmara dos Deputados, Rio de Janeiro, 1879.

75 Christian Edward Cyril Lynch, "Entre o liberalismo monárquico e o conservadorismo republicano: a democracia impossivel de Rui Barbosa", op. cit., p. 46.

76 Rui Barbosa, Discursos parlamentares: Obras completas de Rui Barbosa, 1879, op. cit., p. X. Prefácio por Fernando Néry. 
Mas ainda que destacado como um individuo fisicamente 'frágil', Hermes Lima $^{77}$ descreve Rui Barbosa como um militante do Partido Liberal ainda no período monárquico brasileiro, quando este tinha apenas 24 anos e lutava a pela liberdade religiosa e pelo voto direto. No mesmo sentido, sua inquestionável coragem rendeu-lhe algumas complicações, como por exemplo o comprometimento do seu lugar entre o corpo de deputados depois de 1884, quando demonstrou sua posição favorável ao abolicionismo.

No que concerne as inspirações estrangeiras, tem-se que John Stuart Mill foi um filósofo demasiado importante na construção do pensar liberal de Rui Barbosa, chegando a ser considerado por ele "o maior pensador político do nosso tempo, o autor dos melhores livros modernos sobre a democracia e a liberdade, o sábio bem temperado nas suas opiniões". ${ }^{78}$

Sobremodo, Rui filiou-se à tradição anglo-americana, esta que colocava a moral e o direito como elementos precedentes a política. A referida tradição, na visão de Christian Lynch nasce como junção do republicanismo cívico ao constitucionalismo antiquário. Sendo que, estas duas ideologias, observavam o bem-estar da sociedade política como dependente de instituições limitadas por um ordenamento jurídico específico, ainda que representativas do poder público. Deste modo, predominava "uma concepção pluralista do político, na qual o direito do indivíduo, compreendido como produto da vontade histórica e fundamento da ordem legitima, formatava a esfera de manifestação da soberania"79.

Entretanto, na ótica de Antonio Paim o federalismo idealizado por Rui Barbosa e reclamado por várias gerações liberais, nunca fui praticado no cenário nacional ${ }^{80}$. Vê-se, desta maneira, que as mãos dos Estados na economia, "antes de serem resultantes do colapso da economia exportadora, foram um produto exatamente desta economia exportadora". ${ }^{81}$ Desta maneira, Rui não se conformou com a oposição à liberdade nos anos iniciais da Primeira República, defendida pelo democratismo jacobino, bem como pelo conservadorismo oligárquico. ${ }^{82}$

Rui Barbosa construiu o ideal de uma República visando superar, nas questões democráticas, o Império brasileiro, haja vista as traições e

77 Rui Barbosa, Queda do Império: diário de noticias - Obras completas de Rui Barbosa, Vol. XVI, Tomo I, Ministério de Educação e Saúde, Rio de Janeiro, 1947. Prefácio e notas de Rui Barbosa em 1921.

78 Rui Barbosa, Cartas de Inglaterra, Tomo 2, Iracema, São Paulo, 1966, p. 22.

79 Christian Edward Cyril Lynch, "Entre o liberalismo monárquico e o conservadorismo republicano: a democracia impossivel de Rui Barbosa”, op. cit., p. 40.

80 Antonio Paim, História do liberalismo brasileiro, op. cit., p. 130.

81 Steven Topik, A presença do Estado na Economia Politica do Brasil: de 1889 a 1930, op. cit., p. 194.

$82 \mathrm{O}$ poder político da era republicana é fundamentado pelo autoritarismo, o que teria estimulado insurreições armadas, como em 1893 nas revoltas armadas, na revolta da vacina em 1904 e na revolta da chibata em 1910, todas sediadas na capital federal da época (Rio de Janeiro). Outrossim, a insurreição de Canudos e a guerra do contestado (1897 e 1914, respectivamente) representam rebeliões que eram aniquiladas por meio da força de campanhas de guerra. Ademais, conforme previsto na Constituição Federal de 1891 o estado de sítio (arts. $6^{\circ}$ e 81), o controle de constitucionalidade (arts. 59, § $1^{\circ}$, “a" e "b") e a intervenção federal (art 6) eram os três remédios aplicáveis às situações supracitadas, conforme a Constituição da República dos Estados Unidos do Brasil, op. cit. 
favorecimentos de desejos pessoais pelo corpo político do período. Mas sem força para gerir sozinho a politica republicana, acabou por se iludir frente a realidade que lhe era apresentada.

Assim, observando a antiga monarquia e a atual forma de governo, Rui Barbosa deparou-se com uma contradição: seus planos políticos, jurídicos e econômicos eram frágeis frente às possiveis aplicações dentro deste novo e ainda não desbravado cenário republicano. Logo, distanciou-se do partido conservador - liderado por figuras como Campos Sales, Francisco Glicério e Prudente de Morais -, reaproximando-se de monarquistas favoráveis ao liberalismo. Sobretudo, incapaz de se articular frente aos próprios erros cometidos na transição de governo, Rui Barbosa foi impossibilitado de acatar os projetos dos conservadores oligárquicos e dos jacobinos, e viu-se impedido de aceitar $o$ programa liberal restaurador. 83

Como denúncia e crítica à República brasileira, Rui chegou a comentar que o novo regime matava, através de suas práticas, o texto constitucional, e por meio de suas ações irresponsáveis cometia diversas ilegalidades, sem respeitar as limitações parlamentares, e transformando a tribuna em prisões ${ }^{84}$. Nesse mesmo sentido, sustentava:

Não tenho superstição republicana. Não tenho superstição por cousa nenhuma. A religião mesmo que tenho para com Deus, não é uma superstição: é uma crença raciocinada e sincera. Não sou fanático por nenhuma forma de govêrno [...] esta República que aqui está mostra o que são os supersticiosos da República. 8586

Conversando com a citação anterior, tem-se que em uma acalorada discussão, Rui Barbosa ${ }^{87}$ garantiu ser um homem de consciência, concepção aceita até pelos seus inimigos, chegando a dizer: "não sou da raça dos sofistas gregos; sou da raça dos constitucionalistas americanos e dos juristas ingleses". Contrapondo tais colocações, Pinheiro Machado, político conhecido como 'condestável da república' sustentou que as opiniões de Rui Barbosa acerca do regime republicano vagavam de um extremo a outro, com certas interrupções. Em contrapartida, Rui Barbosa afirmou com veemência que suas ideias não eram intermitentes, mas continuas e permanentes, e que o povo poderia comprovar tal alegação.

Nesse mesmo momento, Rui Barbosa afirmou não ter predileção por nenhuma forma de governo, sustentando que antes de qualquer regime, importava a felicidade do seu povo, perguntando a Pinheiro Machado: "quer V. Ex. ${ }^{a}$ comparar a República brasileira com a Monarquia inglesa?" e em sequência

83 Christian Edward Cyril Lynch, "Entre o liberalismo monárquico e o conservadorismo republicano: a democracia impossivel de Rui Barbosa”, op. cit., pp. 39-40.

84 Rui Barbosa, Escritos e discursos seletos, Seleção, organização e notas de Virgínia Cortes de Lacerda, Nova Aguilar - Fundação Casa de Rui Barbosa, Rio de Janeiro, 1960, p. 475.

85 Rui Barbosa, Discursos parlamentares - Obras Completas de Rui Barbosa, Vol. XLI, Tomo III, Rio de Janeiro, 1914, p. 411.

86 Desde a monarquia, é defendido a ideia que Rui Barbosa não possuía idolatria por qualquer forma de governo, tendo apenas o objetivo de republicanizar a monarquia, a fim de fazê-la caminhar em harmonia com os moldes constitucionais estipulados.

87 Rui Barbosa, Discursos parlamentares - Obras Completas de Rui Barbosa, op. cit., p. 410. 
Pinheiro Machado pontuou que a república "[era] a única que [poderia] elevar uma nação ao apogeu da civilização" e por isso tem a forma republicana como predileta $^{88}$. Ironizando tais afirmativas, Rui Barbosa declarou que Pinheiro Machado fora "sincero nas suas ideias republicanas, mas inventou e sustentou por quatro anos o Gôverno Hermes, êsse Govêrno que arruinou o pais e criou a ditadura militar" e ainda assim (Pinheiro Machado) teve o cinismo de se apresentar como mais republicano que ele (Rui Barbosa). ${ }^{89}$

Em 1921, Rui Barbosa revisitando o passado e se reconhecendo àquele tempo monarquista parlamentar, pontuou que queria 'republicanizar' a monarquia a fim de conservá-la e enquadrá-la nos moldes constitucionais, para assim deixar o governo nas mãos do povo e do parlamento, conforme previsto no ordenamento jurídico. Nessa esteira, pensava que não havia liberdade na monarquia sem que esta não fosse republicana. Em concordância com o que foi dito, mas vivendo agora em um ambiente republicano, Rui pontuou que: "é assim que, republicano sob o império, por querer a monarquia constitucional, havia eu de vir a ser taxado, com a mesma lógica e justiça, de monarquista, na república, por não admitir a república senão dentro na Constituição". 90

Nota-se, portanto, que Rui Barbosa se viu solitário frente ao cenário republicano de caráter autoritário e oligárquico. Logo, voltou-se para o grupo liberal da Monarquia. Sobretudo, ainda que houvesse proferido elogios ao Império (ações estas que o comprometeram em várias situações), Rui não defendeu em nenhum de seus escritos e discursos a restauração da Monarquia, tampouco do parlamentarismo. 91

Ainda que solitário, Rui Barbosa foi uma expressiva figura na área jurídica na era republicana, estando sempre comprometido nos debates de cunho constitucional do período. Seu envolvimento se deu desde os documentos normativos primários desenhados pelo Governo Provisório até aos acalorados debates no tocante a revisão constitucional, antes mesmo da aprovação da Emenda Constitucional em 1926, como demonstra a vasta obra de seu punho.

Além dos pontos citados, Rui Barbosa também se candidatou a Presidência da República, filiando-se ao Partido Civilista ${ }^{92}$, e em uma de suas conferências pela Campanha Civilista ${ }^{93}$, afirmou:

88 Pinheiro Machado pertencia ao grupo dos conservadores castilhistas, que detinha uma concepção ética da República, motivo pelo qual fomentou a predileção pela República como forma de governo.

${ }^{89}$ Rui Barbosa, Discursos parlamentares - Obras Completas de Rui Barbosa, op. cit., p. 412.

90 Rui Barbosa, Queda do Império: diário de notícias - Obras completas de Rui Barbosa, 1921, op. cit., pp. XXVI-XXVII.

91 Christian Edward Cyril Lynch, "Entre o liberalismo monárquico e o conservadorismo republicano: a democracia impossivel de Rui Barbosa", op. cit., p. 61.

92 Rui Barbosa, Ruínas de um Governo: o governo Hermes, as ruínas da Constituição, a crise moral, a justiça e manifesto à Nação, op. cit., p. 8.

93 "Expressão criada para designar a campanha de Rui Barbosa nas eleições presidenciais de 1910. Mais do que lembrar o fato de que Rui era um jurista, a expressão deixava claro que Rui representava a opção civil à candidatura militar do marechal Hermes da Fonseca" (Eduardo Junqueira, Campanha civilista, op. cit., p. 1). 
acceitando a candidatura, que se me impunha com o peso de uma cruz, com a esperança da victoria nas urnas, e a perspectiva da espoliação no Congresso, para affirmar os direitos do paiz contra a usurpação, que se aproximava, tinha eu de lhe arrancar a mascara, e rasgando, sem temor nem piedade, todos os véos, em que se envolve o poder das trevas, expor, em toda a sua enormidade, facilmente prevista, a truculência e a ignomínia dos males, que nos aguardavam. ${ }^{94}$

Lutava, sobretudo, contra os abusos e autoritarismo, denunciando os crimes da ditadura, assim como as práticas politicas que, roubavam a nação e suprimiam desta através das decretações dos estados de sítio. Desta maneira, a coalizão politica era cínica e esbravejava hipocrisia, pois enquanto os politicos falavam em valor da honestidade, do patriotismo e da justiça, agiam de maneira antagônica a tais colocações.

Tem-se que durante 35 anos, os politicos republicanos conseguiram embarreirar qualquer tentativa de reforma à Constituição. Entretanto, depois de tanto tempo, o ânimo de não a reformar foi sendo enfraquecido. Nesse sentido, em 1910, frustrado e insatisfeito com a obra de que foi coautor, Rui Barbosa torna-se adepto ao revisionismo, ainda que timidamente. Assim, na supracitada campanha presidencial em 1910, trouxe a público um projeto solidificado em amplas medidas de reforma, que tratavam desde a revisão constitucional, alterações na esfera financeira, na ampliação do crédito, até mesmo à edição de um novo Código Civil.

Além dessas medidas, Rui Barbosa tinha a esperança de reformar o processo eleitoral, a fim de substituir nos municipios o processo de alistamento por um tipo de registro civil eleitoral. Sobretudo, acreditava e defendia maior equilíbrio do Poder Judiciário dentro do processo eleitoral, e pregava a favor do pleito secreto. Desta maneira, o projeto reformador mostrado pelo então candidato à Presidência da República, achou solo fértil nas camadas médias urbanas, mas recebeu grande represália pelas oligarquias politicas, haja vista que estas dependiam do funcionamento de um sistema sustentado pelo voto aberto, pelo clientelismo e pela politica dos governadores. ${ }^{95}$

Para Rui Barbosa, vários pontos eram intocáveis no processo de revisão constitucional, exemplos são a intangibilidade da Declaração dos Direitos e Garantias, a federação e a república. Em contrapartida, outros pontos deveriam ser modificados, a fim de fortalecer a liberdade e democracia. Um dos pontos a ser alcançado era a restrição ao estado de sítio e outros intervencionismos ${ }^{9697}$. Posicionava-se, portanto, contrário ao intervencionismo feito de modo abusivo,

94 Rui Barbosa, Ruinas de um Governo: o governo Hermes, as ruinas da Constituição, a crise moral, a justiça e manifesto à Nação, op. cit., p. 13.

95 Eduardo Junqueira. Campanha civilista, CPDOC, p. 23.

96 Rui Barbosa, Excursão eleitoral: Obras completas de Rui Barbosa, Vol. XXXVI, Tomo I, Ministério da Educação e Cultura, Rio de Janeiro, 1909. Prefácio escrito por José Maria Belo, p. 27.

97 Não se faz surpreso conceber que, para Rui Barbosa, o governo Hermes era opressor, e nesse sentido afirmava com veemência que "não ha exemplo, em toda a historia, de que o dominio da espada não seja desastroso á liberdade, e se concilie com o império da lei” (Rui Barbosa, Ruínas de um Governo: o governo Hermes, as ruínas da Constituição, a crise moral, a justiça e manifesto à Nação, op. cit., p. 15). 
arbitrário e com vícios de execução. Logo, era a favor de uma intervenção sem excessos, baseado em um texto constitucional que delimitasse com clareza as forças interventivas, uma vez que sem clareza constitucional, a lei acabava por favorecer os mais poderosos, sujeitando os mais fracos a estes.

Entretanto, vale mencionar que em determinados momentos, Rui Barbosa chegou a questionar a pertinência da reforma constitucional - ao levar em consideração pontual equilíbrio econômico -, o que fica mais bem ilustrado em uma sessão no Senado, quando o senador Antônio Azeredo é confrontado por Rui Barbosa acerca do momento adequado para uma revisão na Constituição Federal de 1891. Assim, Rui Barbosa pontua em sua fala que todos são revisionistas, sendo uns "regulares" e outros "oficiais". Nessa linha, explica que os primeiros são os que desejam a reforma constitucional a fim de alterar o corpo normativo, enquanto os últimos são aqueles que remodelam administrativamente a Constituição, sem que para isso seja preciso rever o que fora estabelecido nela própria. 98

Nesse interim, Evaristo de Moraes Filho, seu contemporâneo e participante de sua última campanha presidencial, afirmou em uma das colunas no Jornal Correio da Manhã: "Quando, ainda ha pouco, o senador Azeredo - de cuja boa fé não nos é lícito duvidar - levantou a ideia da revisão constitucional, logo nos occorreu que nunca ella fôra menos opportuna". Mas logo em seguida, ponderou que a constituição de 1891 "nunca foi rigorosamente executada, nem seriamente obedecida", e que tal fato poderia ser comprovado de diversas formas. Ainda seguiu dizendo que não era preciso cavar fundo para deparar-se com as inúmeras violações desde 1892 feitas a Constituição, pinçando como exemplo a violação da autonomia dos Estados pela "intervenção supostamente regular", bem como a supressão do artigo 72 -este que tratava das garantias individuais- na realidade republicana, tal como o desrespeito a opinião pública, frente a ausência de eleições diretas e a predileção do Estado à oligarquias. ${ }^{99}$

Mas impossibilitado de permanecer no novo regime autoritário, sendo republicano, ou de voltar à monarquia parlamentar, tendo em vista seu perfil liberal, Rui se deparou com uma realidade intragável, e deste modo refugiou-se, como pai da Constituição, na defesa de uma República democrática, que deveria carregar como preceito o liberalismo, superando desta forma, a monarquia. Assim, para ele, a República não deveria ser confundida com "aquela república real, empírica, cotidiana, do lado de fora de sua janela”. ${ }^{100}$

Mas desde a Campanha Civilista de 1909 a 1913, da oposição aos quatro anos de governo do Marechal Hermes da Fonseca até a campanha presidencial de 1919 e até a sua morte em 1923, Rui Barbosa não parou de proferir duras críticas as chagas do regime republicano. Nesse interim, para José Maria Belo, a campanha civilista foi um marco na história do regime de 1889 , calcado em um substancial esforço em prol da democracia, na procura de fontes legais no voto

98 Rui Barbosa, Discursos parlamentares - Obras completas de Rui Barbosa, Vol. XXVII, Tomo III, Rio de Janeiro, 1900, p. 234.

99 Evaristo de Moraes, "Revisão antirrepublicana", Ano XXIII, n 9.196. Rio de janeiro, 8 de maio de 1924 , p. 4.

100 Christian Edward Cyrill Lynch, Da monarquia à oligarquia: História institucional e pensamento politico brasileiro (1822 - 1930), op. cit., p. 202. 
popular, a fim de desprender-se da tradição oligárquica, herdada pelo Império. Deste modo, foi nesse combate travado em 1909-10, que Rui Barbosa pode "dar toda a medida, renovada dez anos depois, já septuagenário, da sua intrepidez civica". 101

Nessa analogia, Rui Barbosa tentou encontrar um ponto de equilibrio dentro desse ambiente de transição. Deste modo, resguardou-se na Constituição, na busca por um espaço e consideração no âmbito político. Nessa linha, sua fé estava calcada na capacidade do Judiciário -cujo poder empenhava-se para fortalecer- coibir ações autoritárias do governo ou do Congresso Nacional.102 Infelizmente, sua esperança não resultou em consequências tão positivas, haja vista que Rui Barbosa chegou à conclusão que

A defesa do país está mortalmente ferida nos seus centros orgânicos pelo feudalismo da autonomia dos governadores. Um tal sistema não pode subsistir. Se não reformar em prevenção do perigo iminente, há de cair em presença dêle, com a nação sacrificada. A questão da nossa integridade liga-se à da nossa unidade, a da nossa unidade à da reorganização do nosso regímen. ${ }^{103}$

Como se vê nas palavras de Rui Barbosa, a reforma constitucional deveria ser encarada como um remédio para curar as feridas abertas por um governo desorganizado e egoísta. Em contrapartida, Augusto Teixeira de Freitas, exgovernador da Bahia, em um discurso encontrado nos anais do Senado Federal datado no ano de 1908, profere, em uma mistura de elogios e severas críticas, palavras ao então presidente do Senado, Rui Barbosa. Nesse hiato, finaliza sua fala criticando a revisão constitucional e a sua insuficiência em sanar os problemas decorridos na Primeira República. Apontando a ineficácia da reforma "como remédio a esses males", uma vez que quem propõe esquece que tais dificuldades "estão no organismo nacional, e não se curam chagas profundas com panaceias revisionistas". 104

O que se vê, entretanto, é que Rui Barbosa - e seus apoiadores - viam a reforma constitucional não apenas como uma salvação da forma republicana de governo, mas também como uma medida urgente e indubitavelmente necessária para assegurar a nacionalidade brasileira como um todo. ${ }^{105}$

Entretanto, a história conta que Rui não logrou êxito imediato em suas tentativas, não conseguindo se eleger como presidente e falecendo antes da revisão constitucional. Nesse interim, Fernando Néry, em um prefácio dedicado a uma obra do Rui, pontuou que o povo agiu indiferente ao nome glorioso e immortal de Ruy Barbosa, escolhendo em seu lugar "um candidato inculto, inelegivel e não eleito, imposto à nação pelos quarteis e pela cobardia dos

101 Rui Barbosa, Excursão eleitoral: Obras completas de Rui Barbosa, op. cit., pp. IX-XV.

102 Christian Edward Cyrill Lynch, Da monarquia à oligarquia: História institucional e pensamento político brasileiro (1822 - 1930), op. cit., p. 222.

103 Rui Barbosa, A imprensa - Obras completas de Rui Barbosa, Vol. XXVI, Tomo V, Rio de Janeiro, 1899, p. 300.

104 Rui Barbosa, Discursos parlamentares - Obras completas de Rui Barbosa, Vol. XXXV, Tomo I, Rio de Janeiro, 1908, pp. 182-183.

105 Rui Barbosa, A imprensa-Obras completas de Rui Barbosa, 1899, op. cit., p. 229. 
politicos e comodista". Além disso, destacou que ao invés de um "governo da lei, [o povo] preferiu curvar a cerviz ao jugo da espada". ${ }^{106}$

Todavia, apesar de não ter saído vitorioso, suas campanhas presidenciais foram carregadas de significado, e deixaram mensagens importantes sobre a relevância da estabilidade constitucional do país. ${ }^{107}$

Ademais, conforme a Primeira República vai se desdobrando as alterações dentro do texto constitucional republicano parecem ser cada vez mais necessárias, até mesmo para aqueles que antes desacreditaram. Para o jurista João Barbalho "a constituição não poder-se-ia considerar intangivel, imutável e por mais conservador que haja sido o espírito que a ditou nesta parte, não lhe teria escapado que para conservar é preciso aperfeiçoar". ${ }^{108}$

$\mathrm{Na}$ mesma perspectiva, ainda que haja certos desacordos de cunho doutrinário entre o jurista citado no parágrafo anterior com o jurista Carlos Maximiliano ${ }^{109}$, os dois parecem concordar que o texto constitucional original deve modelar-se de acordo com o meio que fora inserido, a fim de que, com a adaptação, a constituição se aperfeiçoe, aumentando a cultura, preenchendo as lacunas feitas por circunstâncias alheias e imprevistas. Demonstra-se, portanto, que para esses juristas a lei superior deveria se adaptar as novas condições que emergissem com o tempo, para que a Constituição não se transformasse em um obstáculo à democracia, levando a uma guerra civil.

O Partido Civilista propunha durante a campanha presidencial a revisão constitucional. Deste modo, adotou-se como primeiro passo desse processo o estabelecimento em comum acordo, dos pontos da Constituição de 1891 que não deveriam ser levados a diante na formulação do projeto de emenda. ${ }^{110}$

Sobre esse prisma de necessidade de mudança, Rui Barbosa aponta em seu discurso presidencial em 1919 que "o Brasil atravessa [...] uma crise característica de febricitação". Com isto, o então candidato à presidência sustentou que alterações deveriam ser feitas dentro do corpo da Primeira República a fim de dar cabo aos "micróbios e fagocitas" que adoeciam a política. ${ }^{111} \mathrm{E}$ é sobre esse sustentáculo que a ideia de revisão constitucional se desdobrou no seio social como uma maneira de conciliação nacional e alterações positivas que resultariam na união nacional. ${ }^{112}$

Rui Barbosa afirmava que os antagonistas à revisão constitucional já realizaram a sua própria revisão, a fim de satisfazer os ensejos da sua facção e

106 Rui Barbosa, Ruínas de um Governo: o governo Hermes, as ruínas da Constituição, a crise moral, a justiça e manifesto à Nação, op. cit., p. 8.

107 Priscila M Pivatto, Discursos sobre o Estado de Sitio na Primeira República Brasileira: Uma abordagem a partir das teorias de linguagem de Mikhail Bakhtin e Pierre Bourdieu, op. cit., p. 137.

108 João Barbalho, Constituição federal brazileira: commentarios, Imprenta: Typ. da Companhia Litho-Typographia, Rio de Janeiro, 1902.

109 Carlos Maximiliano, Comentários à Constituição brasileira, $2^{\mathrm{a}}$ ed, Jacintho Ribeiro dos Santos, Rio de Janeiro, 1923, p. 754.

110 Priscila M Pivatto, Discursos sobre o Estado de Sítio na Primeira República Brasileira: Uma abordagem a partir das teorias de linguagem de Mikhail Bakhtin e Pierre Bourdieu, op. cit., p. 137.

111 Rui Barbosa, Campanha presidencial: Obras completas de Rui Barbosa, op. cit., p. 18.

112 Rui Barbosa, Campanha presidencial: Obras completas de Rui Barbosa, op. cit., p. 114. 
governar o Estado. Estes, apontava Rui Barbosa, "não querem saber da Constituição federal, senão até onde lhes sirva ela de barreira protetora ao monstro positivista contra a intervenção republicana". Deste modo, ele descreve a revisão constitucional como um privilégio, e delineia que os que a "escoiceiam" não pediram licença para alterar o texto constitucional conforme seus desejos privados, além disso não concedem licença a mais ninguém para tocar na Constituição de 1891.113

Ao analisar os apontamentos feitos neste capitulo, percebe-se que Rui Barbosa, um dos indivíduos responsáveis pela instituição da Constituição Federal de 1891, teve seu discurso transformado frente à realidade republicana. Este que tinha sua fala sustentada por um ideário liberal, teve que, para garantir a democratização do período, pedir durante os anos que seguem a Primeira República a intervenção e reforma no texto constitucional original de 1891. Assim, com o passar dos anos, Rui Barbosa passou a crer que o salvatério do país estava na revisão do texto constitucional. ${ }^{114}$

Desta maneira, a revisão constitucional seria essencial para dar competência ao Poder Legislativo, a fim de que este tomasse medidas que solucionassem os problemas sociais reclamados. Uma vez que caso a Constituição não fosse revista, o Congresso Nacional não teria força normativa para legislar sobre a questão social e seus aspectos mais importantes. ${ }^{115}$ Nesse hiato,

Acreditando eu que as instituições se conservam, quando adotam, a tempo, as reformas necessárias, convenci-me de que, sem a revisão, a Carta republicana de 1891 está perdida. Vendo, por outro lado, que os interesses oficiais da política brasileira, senhores absolutos do País, estão invencivelmente coligados em negar a revisão constitucional. ${ }^{116}$

Sobretudo, fala-se sobre a questão social porque uma parcela da população estava insatisfeita com o regime constitucional adotado, haja vista os inúmeros abusos em sua aplicabilidade, as lacunas e brechas constitucionais que acabavam mesmo que indiretamente, ferindo a sociedade. Assim, frente ao descontentamento do corpo social, "pacificadores" se uniram para defender estas causas, tendo em vista a "insalubridade política" daqueles que às reclamavam, unindo uma só força para a reforma constitucional. ${ }^{117}$

Um outro ponto que deve ser considerado é que seria melhor realizar a revisão da Constituição, nos pontos necessários, do que fazer com que a massa populacional criasse aversão ao texto constitucional, ou ainda provocar uma indesejada arbitrariedade por meio de maior concessão de poder ao Poder

113 Rui Barbosa, Campanha presidencial: Obras completas de Rui Barbosa, op. cit., pp. $116-117$.

114 Rui Barbosa, Discursos - Obras Seletas de Rui Barbosa, Vol. XLVIII, Tomo II, Rio de Janeiro, 1923, p. 75.

115 Rui Barbosa, Campanha presidencial: Obras completas de Rui Barbosa, op. cit., p. 110.

116 Rui Barbosa, Discursos - Obras Seletas de Rui Barbosa, op. cit., p. 78.

117 Rui Barbosa, Campanha presidencial: Obras completas de Rui Barbosa, op. cit., p. 114. 
Legislativo. ${ }^{118}$ E é nesse sentindo que o movimento revisionista liderado por Rui Barbosa, e outros movimentos, há vários anos, desejavam corrigir as imperfeições da Carta de 1891, a fim de fortalecer o liberalismo e a democracia. ${ }^{119}$

Conquanto, para o jurista Castro Nunes muito da dificuldade à revisão constitucional adveio de uma mentalidade criada, esta que considerava o projeto de revisão inoportuno ao tempo, ainda que não fosse considerado necessário em alguns aspectos. Logo, tal argumento fazia com que a revisão fosse vista com certa hostilidade, circunstância suficiente para fechar portas a qualquer proposta de revisão ${ }^{120}$.

Outrossim, ainda que o movimento em prol da revisão constitucional fosse bastante presente durante toda a primeira república, a forte diferença de interesses de seus defensores foi fator substancial para enfraquecer os movimentos revisionistas. ${ }^{121}$

Seria apenas em meados da última década do período, mais precisamente em 1924, que o Congresso Nacional apresentaria o primeiro projeto de reforma, ainda que todo o período da Primeira República fosse marcado por um constante debate acerca da necessidade de adaptação da Constituição Federal frente a realidade brasileira peculiar. Não obstante, para Eduardo Junqueira a proposta de reforma constitucional formou-se um momento inoportuno, mesmo depois de trinta décadas de debate. ${ }^{122}$

O projeto de reforma constitucional encontrou opositores à forma como fora orquestrado, porque para estes o poder Executivo não teria competência para levar o projeto a bancada governista da Câmara e apresentá-lo como de sua autoria. Deste modo, tal objeção gerou a hipótese de nulidade do revisionismo constitucional, tendo como alegação a quebra de preceitos contidos no artigo 90 da lei suprema. Em seguida, o conteúdo do projeto foi duramente questionado, uma vez que, para muitos republicanos, a concessão de maiores possibilidades de intervenções nos estados e a supremacia do Poder Executivo sobre os demais poderes, não só feria, mas dava fim ao modelo federalista.

Depois de tramitar nas duas casas do Congresso Nacional, anulou-se do projeto os capítulos que colocavam em ameaça o pacto federativo e as liberdades individuais, além de extirpar a diminuição da aplicabilidade do estado de sítio. Entretanto, observando a emenda constitucional aprovada pode-se notar que muitos dispositivos permaneceram, e muitos entraram como emendas

118 Rui Barbosa, Campanha presidencial: Obras completas de Rui Barbosa, Vol. XLVI, Tomo II, Rio de Janeiro, 1919, p. 256.

119 Aliomar Baleeiro, Coleção Constituições brasileiras: 1891, op. cit., p. 49.

120 José de Castro Nunes, A Jornada Revisionista: os rumos, as ideias, o ambiente, Pap. Almeida Marques \&, Rio de Janeiro, 1924, p. 3.

121 Priscila M Pivatto, Discursos sobre o Estado de Sítio na Primeira República Brasileira: Uma abordagem a partir das teorias de linguagem de Mikhail Bakhtin e Pierre Bourdieu, op. cit., p. 141 .

122 Eduardo Junqueira, Reforma da constituição de 1891, op. cit., pp. 1-2. 
substitutivas. ${ }^{123}$ Nessa linha, no ano de 1926 foram aprovadas cinco emendas à Constituição. ${ }^{124}$

Com base nas colocações anteriores, parece que a adoção de emendas constitucionais, desdobram-se na verdade, em uma contrarreforma, já que as alterações feitas no texto constitucional de 1891 contrariam de modo indubitável as propostas politicas feitas anos antes da própria revisão. Logo, a revisão do texto de 1891 demonstra as últimas forças politicas das oligarquias cafeeiras, elas que haviam dominado as instituições públicas durante vários anos da Primeira República. ${ }^{125}$

Nessa esteira, com a emenda constitucional de 1926, as exceções existentes no artigo $6^{\circ}$ da Constituição de 1891 foram acrescidas de modo expressivo, permitindo, portanto, a intervenção do Governo federal nos Estados para assegurar determinados principios fundamentais, para manter o livre exercício dos poderes públicos estaduais e pôr cabo a guerra civil, para garantir a efetividade de sentenças e leis federais e remodelar as finanças dos Estados que não demonstrarem autonomia para cessar pagamentos de dividas por mais de dois anos. ${ }^{126}$

Por analogia, ficou estabelecido com a emenda de 1926 a competência privativa do Congresso Nacional "para decidir da legitimidade de poderes, em caso de duplicata $\left(\mathrm{n}^{\circ}\right.$ III), e para reorganizar as finanças do Estado insolvente". Além disso, instituiu-se que o Supremo Tribunal Federal poderia requisitar ao Poder Executivo a intervenção dos Estados, para garantir a execução de sentenças federais. ${ }^{127}$

A Emenda Constitucional de 1926, entre outras alterações, concedeu a possibilidade do veto parcial, sendo regulado pelo artigo $37, \S 1^{\circ}$, do texto constitucional de 1891. Deste modo, o Presidente da República, poderia julgar um projeto de lei, no todo ou em parte, inconstitucional ou contrário aos interesses nacionais, possibilidade antes inexistente, tendo em vista que só cabia veto total, método que se assemelhava aos Estados Unidos. ${ }^{128}$

No que respeita ao habeas-corpus republicano, tinha-se que esse era uma garantia constitucional, assegurado pelo artigo $72 \S 22$ da Constituição de 1891 , e era concedido sempre que um individuo sofresse ou se achasse em iminente perigo de sofrer algum tipo de violência ou coação por meios ilegais ou por abuso de poder. Todavia, com a emenda de 1926, o habeas corpus ${ }^{129}$ foi limitado, sendo

123 Eduardo Junqueira, Reforma da constituição de 1891, op. cit., pp. 2-3.

124 Priscila M Pivatto, Discursos sobre o Estado de Sitio na Primeira República Brasileira: Uma abordagem a partir das teorias de linguagem de Mikhail Bakhtin e Pierre Bourdieu, op. cit., p. 144.

125 Priscila M Pivatto, Discursos sobre o Estado de Sitio na Primeira República Brasileira: Uma abordagem a partir das teorias de linguagem de Mikhail Bakhtin e Pierre Bourdieu, op. cit., p. 162.

126 Emenda constitucional de 3 de setembro de 1926. Rio de Janeiro. Emendas à Constituição Federal de 1891.

127 Emenda constitucional de 3 de setembro de 1926, op. cit.

128 Constituição da República dos Estados Unidos do Brasil, op. cit.

129 O habeas corpus foi assunto bastante debatido antes e depois da Emenda Constitucional de 1926. Como demonstração disso, pode-se encontrar em uma das colunas de um jornal da época, Evaristo de Moraes criticando a supressão desse remédio constitucional. Sobretudo, reconhecendo algumas falhas na aplicação da lei, mas compreendendo que falhas acontecem em todos os institutos jurídicos, não sendo justificativa suficiente reformar o texto legal. O medo do autor era, portanto, "de retroceder, de voltar á adopção de um principio mais acanhado" (Evaristo de Moraes, "Revisão antirrepublicana", op. cit., p. 4). 
concedido somente quando alguém sofresse ou se achasse em iminente perigo de violência ocasionado por meio de prisão ou constrangimento ilegal sobre a liberdade de locomoção. ${ }^{130}$

Torna-se evidente, portanto, que a reforma de 1926 foi o resultado de um processo desenvolvido desde os primeiros anos da era republicana. ${ }^{131}$ Mas ainda assim, muitas mudanças que derivaram da Emenda Constitucional de 1926 não conseguiram satisfazer as aspirações daqueles que lutaram pela revisão constitucional desde o início da Primeira República.

\section{CONSIDERAÇÕES FINAIS}

Em um primeiro ponto, por meio do estudo sobre as ações do governo dentro do cenário republicano e as políticas de valorização de produtos instituídas por este, demonstra-se forte intervenção nas relações econômicas. Ademais, a Convenção de Taubaté frente a crise econômica ocasionada pela desvalorização do café demonstra um mecanismo do Estado para regular o mercado interno, mas também o externo.

Outrossim, ao analisar a Constituição de 1891 dentro do período, pode-se notar que ela, como texto maior, não foi capaz de se sustentar, tal como o seu liberalismo. Não obstante, Rui Barbosa, politico liberal, candidato à presidência, posicionava-se a favor de uma reforma constitucional que regulasse de maneira mais efetiva a intervenção do governo federal, principalmente no que diz respeito a questão social. Ele, como liberal e um dos criadores da Constituição de 1891, demonstra a falta de força e aplicabilidade do texto constitucional, assumindo desta forma que o liberalismo naquele momento não era viável, tampouco a Constituição de 1891, que para ele, com o tempo, deixou de satisfazer o povo brasileiro.

Desta maneira, Rui Barbosa viu-se entre a memória agradável da Monarquia Parlamentar e a realidade abismal da República presidencial, assumindo a figura de pai da Constituição e um intérprete vivo das intenções desenhadas nesse texto constitucional.

O que se viu, entretanto, é que a Primeira República, firmada por um golpe em 1889, solidificada por uma constituição de cunho liberal, não conseguiu (exceto pelo discurso político- jurídico) reger suas ações de acordo com o texto constitucional. Sobretudo, ainda que houvesse o desejo pela reforma constitucional, vê-se que esta demorou para ser efetuada, e tal fato se deu pelo iminente conflito de interesses daqueles que desejavam a reforma. Nessa linha, é congruente apontar que a Emenda Constitucional de 1926 não trouxe mudanças significativas na esfera social, tampouco na econômica.

Fecha de envío / Submission date: 11/02/2021

Fecha de aceptación / Acceptance date: 27/04/2021

\footnotetext{
130 Emenda constitucional de 3 de setembro de 1926, op. cit.

131 Priscila M Pivatto, Discursos sobre o Estado de Sítio na Primeira República Brasileira: Uma abordagem a partir das teorias de linguagem de Mikhail Bakhtin e Pierre Bourdieu, op. cit., p. 139.
} 